\title{
Research Notes: The Integration of European Mortgage Laws
}

\section{Rebecca Sanders}

THE INTEGRATION OF EUROPEAN MORTGAGE CREDIT MARKETS REPRESENTS PART OF an ongoing attempt to create a single market for retail financial services within the European Union (EU). The aim of this process is to eliminate disparities between Member States in lending practices so as to create favourable conditions to both borrowers and lenders, thereby creating a single market for mortgages products. My thesis seeks to explain why the Commission thinks it would be beneficial to integrate mortgage law across the EU Member States; and how this process is being undertaken. To this end, the thesis considers the interface between law and policy, through using various governance methodologies or frameworks.

Within the current financial climate, the regulation of mortgages is increasingly significant. The impact of the failure of the American sub-prime lending market has had global repercussions, not limited solely to financial services markets but to the economy in general. This indicates a need for strong and stable mortgage markets in order to provide for economic strength and growth. Although the process of integration within Europe pre-dates the collapse of the American market, this will certainly have impacted upon the way in which any EU-level measures are ultimately undertaken and furthermore makes the process more economically significant.

The integration of mortgage laws is a newly developing area. At the same time, it is representative of the Europeanization of policy areas, which is becoming increasingly prevalent as a result of the evolution of the single market (Bulmer \& Radaelli 2004). This specific area of law will therefore increase general understanding of the functioning of the internal market.

\section{Why does the Commission think it would be beneficial to integrate mortgage law?}

The Commission has identified disparities between national laws as potentially restricting the level of cross-border mortgage activity within the EU. These disparities effectively create restrictions upon cross-border services provision, freedom of establishment and free movement of capital. The Commission suggests that integrating the mortgage credit markets of the Member States will create a more favourable environment for both lenders and consumers (See EC 2007a, 2007b).

Furthermore, studies carried out on behalf of the Commission (London Economics 2005; Mercer Oliver Wyman 2003) indicate a potential growth in gross domestic product based upon projections of increased cross border mortgage activity. This aim

\footnotetext{
This article has been written by a student participant of the 'Legal Research Methodologies in European Union and International Law' workshop series as detailed in the three Research Notes articles by Hervey et al. (2007, 2008a \& 2008b). The article introduces the student's PhD project and details some of the methodological research issues which the AHRC funded workshops have helped the student to address.
} 
was originally formulated, in particular through the strengthening of sub-prime markets, in order to create an internal mortgage market capable of competing within the global economy, and in particular, to compete with the American mortgage market (London Economics 2005).

Analysis of the Commission policy documents provides insight both into why this policy was originally formulated and also whether lessons can be learned from the collapse of the American sub-prime lending market. Implicit within the process of integration of EU mortgage law is the notion that the actions of the Commission are central to the development of European law.

\section{How is this process taking place? \\ A rational choice institutional analysis of the policy network}

My main aim is to examine how the Commission is planning to integrate mortgage laws across the EU. This will require an examination of both law and policy.

The process of integrating mortgage laws across the EU is currently being undertaken through a policy network instigated by the Commission, consisting of bodies of actors with shared interests in the process. The network both identifies policy objectives and determines methods to achieve these. It largely comprises representatives from national consumer groups, mortgage industry representatives and financial service authority members. An extensive consultation process with these stakeholders identified a broad range of potential policy objectives. The process aimed to identify areas of policy which may require regulation for the benefit of both primary and secondary mortgage markets. ${ }^{1}$ The process also focused upon how these objectives may best be achieved.

Through analysis of the responses of stakeholders within the network, the Commission has identified the best type of governance for each of the policies in order for successful implementation. This has resulted in a range of policy options within a continuum covering a wide variety of types of governance. The options considered range from doing nothing and leaving it to market forces, through non-binding, 'soft law' methods (e.g. scoreboards as used in OMC, guidelines, industry self-regulation) to traditional EU legislation (e.g. enforcement of existing EU legislation or new legislation) (EC 2007a, 2007b).

Although studies of policy networks are a useful tool for understanding or describing the actions of a network within a particular sector, the exploration of policy networks can potentially be somewhat limited (Rhodes 1986; Peterson 2003). In this study policy networks analysis will be used to explain the way that policy has developed within the particular sector of mortgage laws. Further insight can however be gained as to why certain policy decisions are made through the application of an actor-based methodological approach. This provides a useful analytical tool to understand the behaviours and decisions of the policy network. Rational choice institutionalism will be used as an actor-based approach which is consistent with policy network analysis. The operation of rules is significant to both types of analysis.

Within institutionalism, the operation of rules can be seen to determine the balance of power between participants, the actions taken and the outcomes determined (Ostrom 1986). Similarly, the policy network is constrained by a series of 'rules of the game', which determine the way in which members are capable of interacting and influencing policy decisions. This term is traditionally used to refer to the factors which constrain

\footnotetext{
${ }^{1}$ The regulation of primary mortgage markets concerns transactions between industry and consumers. Secondary mortgage markets concern the bundling and sale of mortgages as between financial institutions, in a process of securitisation.
} 
the internal interactions within a network, including such factors as consensus, fairness and secrecy. It can also be used to refer to external constraints upon the limits of power of the network, "the right to govern", (Rhodes 1986). Within the context of the EU the concept of institutionalism can be extended to include the constraints of internal market law and its use as a resource (Armstrong \& Bulmer 1998).

By applying an institutionalist framework to the actions of the policy network, these rules can be seen as an institution (Blom-Hansen 1997). The network is viewed as operating within a set of rules governing the way in which policy outcomes are determined through combining the observation of the operative rules with an actor based model of integration theory. This approach is one which has been advocated as useful for providing greater analytical insight into the operation of policy networks (Blom-Hansen 1997) and will therefore provide greater insight into how policy decisions are made, given the diversity of members within the network and the often competing aims of actors.

\section{The relationship between policy and law}

Traditionally, policy network studies and new institutionalist approaches focus on the political interactions taking place. Thus policy networks can be characterised as pressure groups aiming to bring about change. Similarly new institutionalist approaches are studies pertaining to the non-neutrality of institutions, which are capable of impacting upon the ability of groups to contribute to the development of policy (Blom-Hansen 1997). This study will go beyond these insights to consider the relationship and interactions between law and policy in the field of European mortgage integration.

EU internal market law can be seen as a starting point within the integration process. Disparities between national laws have potentially detrimental effects upon the operation of the Treaty's 'fundamental freedoms'. Thus, it is the objective of removing legal barriers to the internal market and the opportunity to do so, based on the powers given in the Treaty to create and sustain the internal market that has enabled the Commission to act. It is therefore clear that law also falls within the 'rules of the game' which regulate the activities of the policy network and institutions. The EU legislature may not act beyond its competences. Hard law is available where a Treaty basis permits it. Non-binding measures may be permitted where hard law is not. Any policy must be consistent with the already existing legal framework of the Capital Requirements Directive and the Data Protection Directive.

Law can also be seen as an end point to the policy development process. The range of options available as methods of achieving policy objectives comprises both binding and non-binding approaches. A traditional method of achieving integration is through the adoption of binding laws, typically directives. Yet, the non-binding approaches under consideration can also be broadly categorised as law, representative of the shift towards a 'soft law'-based 'new governance' approach to regulation.

Law is therefore both a resource and a potential outcome within the development of an integrated EU mortgage market. In order to understand the significance of the law within the study, a doctrinal analysis of the rules on EU internal market law and existing specific measures on related subjects will be undertaken.

The AHRC Workshop helped me to continue to grapple with the challenges of my interdisciplinary project. As legal scholars, we need to integrate the insights of doctrinal analysis into studies of EU integration that use political science approaches. I hope my thesis will contribute to this general debate, in a new emerging area of EU law and policy. The feedback I received helped me to clarify my aims and to ensure that my approach is consistent with my objectives. Finally, my participation in the workshop 
made me realise that although I tend take a doctrinal approach, the application of alternative methodologies to my work can help me to gain valuable insight.

\section{Bibliography}

Armstrong, K., Bulmer, S. (1998). The Governance of the Single European Market. Manchester: Manchester University Press.

Blom-Hansen, J. (1997) A 'New Institutional' Perspective on Policy Networks, Public Administration, 75 (4), pp. 669-693.

Bulmer S. J, Radaelli, C.M. (2004) 'The Europeanisation of National Policy?', Queen's Papers on Europeanisation; 1/2004, Queen's University Belfast.

Directive 1995/46 on the protection of individuals with regard to the processing of personal data and on the free movement of such data OJ [1995] L281/31

Directive 2006/48 EC relating to the take up and pursuit of the business of credit institutions OJ [2006] L177/1

Directive 2006/49 EC on the capital adequacy of investment firms and credit institutions OJ [2006] L177/201

EC (2007a). White Paper on the Integration of Mortgage Credit Markets, COM (07) 807, final. Available at:

http://eur-lex.europa.eu/LexUriServ/LexUriServ.do?uri=COM:2007:0807:FIN:EN:PDF

EC (2007b). White Paper on the Integration of Mortgage Credit Markets, Summary of the Impact Assessment, COM (07) 807, 1684, final. Available at: http://europapoort.eerstekamer.nl/9345000/1/j9vvgy6i0ydh7th/vgbwr4k8ocw2 /f=/vhqtlwt3j6su.pdf

Hervey, T., Cryer, R. \& Sokhi-Bulley, B. (2007). 'Legal Research Methodologies in European Union and International Law: Research Notes (Part 1)', Journal of Contemporary European Research, 3 (2), pp.161-165.

Hervey, T., Cryer, R. \& Sokhi-Bulley, B. (2008a). 'Legal Research Methodologies in European Union and International Law: Research Notes (Part 2)', Journal of Contemporary European Research, 4 (1), pp.48-51

Hervey, T., Cryer, R. \& Sokhi-Bulley, B. (2008b). 'Legal Research Methodologies in European Union and International Law: Research Notes (Part 3)', Journal of Contemporary European Research, 4 (3), pp.200-204.

London Economics (2005) The costs and benefits of Integration of EU mortgage markets, Report for European Commission DG-Internal Market and Services.

Mercer Oliver Wyman (2003) Study on the Financial Integration of European Mortgage Markets, Report for the European Mortgage Federation.

Ostrom, E. (1986), 'An Agenda for the study of institutions', Public Choice, 48, pp.3-25.

Peterson, J. (2003) Policy Networks. Vienna: Institute for Advanced Studies. p4.

Rhodes, R.A.W. (1986) The National World of Local Government. London: Allen \& Unwin. pp.391-392. 